\title{
Early Immune Responses in Nude Mouse Following Intravenous Injection of Mycobacterium leprae
}

\author{
Fumishige MiNAGAWA, Yuji YOSHINO and MAsahide ABE \\ (National Institute for Leprosy Research)
}

(Received for Publication, August 18, 1977)

Antibody production is known to be principal function of $\mathrm{B}$ cell immune system. Some antigens, for example, sheep erythrocytes, induce in mouse the production of antibodies which necessitates helper function of $T$ cells. Such antigen is called thymus-dependent $t^{1)}$. The antigen of $M$. leprae seems to be thymus-independent, because the antibody-production to this antigen has been demonstrated, as reported previously ${ }^{2}$, in the patients with lepromatous leprosy as well as in immunosuppressed mice both of which are considered to be under the impairment of cell-mediated immunity (CMI). However, there is no evidence that the function of helper $\mathrm{T}$ cells is also impaired. In order to elucidate this problem, athymic nude mouse may be useful, because the animal is known to be lacking in $T$ cell functions while normal in B cell system ${ }^{3)}$. Such an unbalance in immune system may permit an enormous multiplication of $M$. leprae, as successfully demonstrated by Kohsaka et $\mathrm{al}^{4)}$.

Another purpose of present study is to clarify immune responses in nude mice at early stage after the infection of $M$. leprae. Such study is necessary for evaluating immunological tests for leprosy, i. e. indirect fluorescent antibody test and lymphocyte transformation test, both of which have been developed recently and are expected to be useful for early diagnosis of leprosy.

\section{Materials and Methods}

\section{1) Animals}

Specific pathogen-free, BALB/c-nu/nu (homozygote, 6 female) and BALB/c-nu/t (heterozygote, 6 male) mice were purchased from Central Laboratory for Experimental Animals (CLEA) Japan Inc., and conventional BALB/c- $+/+(2$ male and 5 female $)$ mice were offered from the laboratory of epidemiology in author's institute. These mice were maintained in the metal cage with filter-cap and fed with sterilized diet and water.

\section{-2) Administration of antigens}

A suspension of $M$. leprae was prepared from lepromatous nodule which had been removed from relapsed patient and kept in a deep-freezer at $-20^{\circ} \mathrm{C}$ for nearly two months. One tenth $\mathrm{ml}$ of saline suspension consisted of 10 million bacilli and 100 million sheep red blood cells was injected intravenously to each mouse at 5-7 weeks age. Six nude mice were reinjected with the same antigens at 5 th week after the initial injection.

3) Transfer of thymocytes 
Six nu/+ mice were sacrificed to obtain thymus cells at 4 th week after the injection of antigens. Thymus cells were pooled in saline and passed through a glass-fiber column. The harvests, 90 million cells were divided into three equal parts and injected intravenously to three out of six nude mice.

4) Serological tests

The blood was taken from tail vein of each mouse using capillary tubes, on the fixed days of the experiment. The method of indirect fluorescent antibody test has been described elsewhere ${ }^{2,5)}$. The smears of $M$. leprae were prepared from subcutaneous leproma of armadillo (L-154 (456)) which had been offered from Dr. E. E. Storrs, Gulf South Research Institute, New Iberia, Louisiana, U. S. A. Instead of fluorescent antibody to human gamma globulin, the following two reagents were used as second antibody: Rabbit antiserum to mouse serum was prepared in author's laboratory and labelled with fluorescein isothiocyanate by dialysis method $^{6)}$, and goat fluorescent antibody to mouse IgG was purchased from Hyland Laboratories, Los Angeles, California, U.S. A. The antibody-titer was expressed by the maximum dilution of mouse serum showing $2+$ fluorescence of bacilli in the light passed through BV or interference filter system. Agglutination and hemolysin titers to sheep red blood cells were determined with microtiter plates.

5) In vitro test on transformation of spleen cells

This test was performed at the sacrifice of mice. Ten to 30 million spleen cells/tube were mixed with sonicated suspension of $M$. leprae in the medium RPMI 1640 containing $5 \%$ human serum and cultured at $37^{\circ} \mathrm{C}$ for 4 to 5 days in a $\mathrm{CO}_{2}$-incubator. The transformation of stimulated cells was measured by the uptake of tritiated thymidin which was added to each tube prior 24 hours of the end of cultivation. The stimulation index (SI) was expressed by the ratio of average radioactivity (cpm) in triplicate test tubes containing antigen to that in controls without antigen.

\section{Results and Discussion}

Macroscopically, all mice showed no external nor internal lesion, except the lack of hair and thymus in nu/nu mice. Anti-M. leprae antibody-titer curves are shown in Fig. 1 . The shape of curves in each group of mouse indicated clear difference according to the use of different fluorescent antibodies up to two weeks after the first antigen-injection. This may be due to initial response of $\operatorname{IgM}$ antibodies followed by delayed production of $\operatorname{IgG}$ antibodies. It is noteworthy that antibody-titer reaches the maximum within 1 to 2 weeks after the injection of $M$. leprae. This seems to support the usefulness of indirect fluorescent antibody technique for early serodiagnosis of leprosy. The antibody-titer in nu/nu mice were not significantly different from those in the other two groups. This fact indicates that antibody production to $M$. leprae is thymus-independent. The transfusion of thymocytes from $\mathrm{nu} /+$ donor did not influence the antibody-titer of recipient nude mice, as shown in the upper part of Fig. 1. Second injection of antigens tends to increase the antibody-titer irrespective of transferring thymocytes (solid line) or not (broken line). As these mice had 


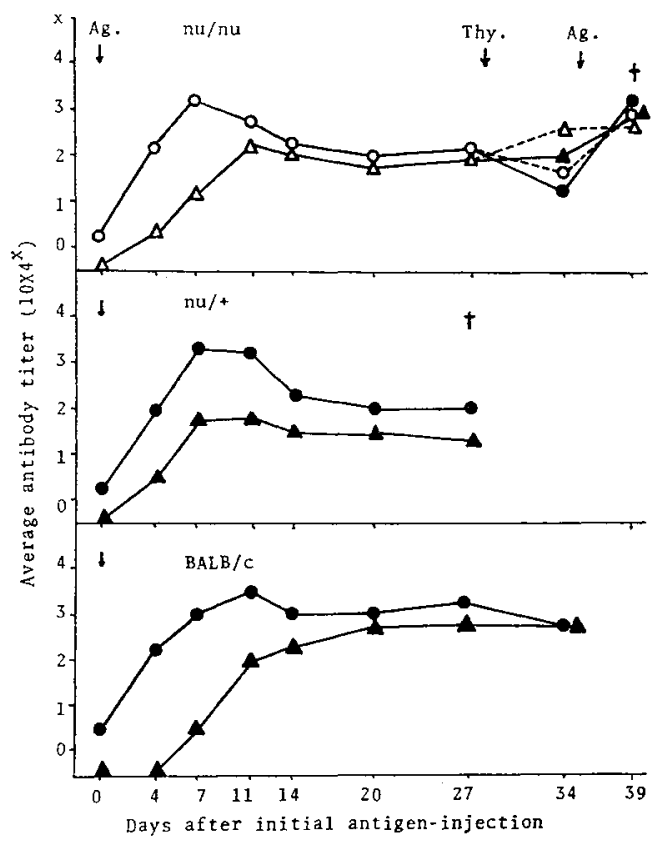

Fig. 1 Anti-M. leprae antibody titers of mouse serum determined by rabbit fluorescent antibody to mouse serum (-O, -) and goat fluorescent antibody to mouse IgG $(-\Delta, \Delta-)$

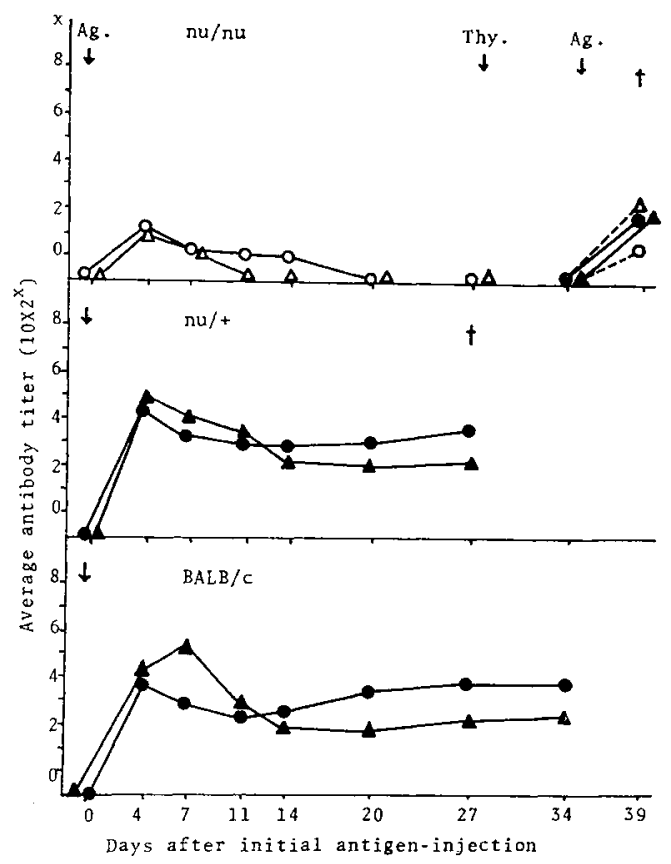

Fig. 2 Antibody-titers of mouse serum in agglutination $(-0,-)$ and hemolysis $(-\Delta$, A-) reactions with sheep red blood cells

to be sacrificed for examining the transformation of spleen cells, further course of secondary immune response could not be followed up.

The antibody-response to sheep red blood cells is shown in Fig. 2. This antigen is known to be thymus-dependent ${ }^{1)}$. In fact, the production of agglutinins and hemolysins in nude mice were significantly lower than those in the other mice possessing thymus. As shown in the middle part of Fig. 2, nu/t mice maintained enough high antiboby-titer by the time of sacrifice. However, the thymocyte-transfer alone did not induce antibody-production in nude mice when examined at 6 th day after the transfer. Both agglutinins and hemolysins appeared in $T$ cell recipients at 4 th day after the second injection of antigens. However, the same titer of hemolysin was also observed in non-recipients. Then, the effects of 2 mercapto-ethanol (ME) on these antibodies was tested with the serum from sacrificed mouse. As shown in Table 1, ME resistant antibody was produced by the most of control mice, but never by any of nude mice, irrespective of the thymocyte-transfer and even after the second injection of antigens. It might be necessary to observe further course of secondary immune response for demonstrating helper function of transferred thymocytes.

In vitro transformation of mouse spleen cells stimulated by $M$. leprae antigens is shown in Table 2. This reaction is considered to be an index of cell-mediated immunity (CMI). When the animal was sacrificed within 6 weeks, no $\mathrm{BALB} / \mathrm{c}$ nor $\mathrm{nu} /+$ mouse caused positive re- 
Table 1 The effect of 2-mercapto-ethanol (ME) on the antibody-titer to sheep red blood cells

\begin{tabular}{|c|c|c|c|c|c|}
\hline \multirow{2}{*}{ Mouse } & \multirow{2}{*}{$\begin{array}{l}\text { No. of } \\
\text { animal }\end{array}$} & \multicolumn{2}{|c|}{ Agglutinin titer* } & \multicolumn{2}{|c|}{ Hemolysin tier* } \\
\hline & & & & & ME treated \\
\hline \multirow{3}{*}{$\mathrm{nu} / \mathrm{nu}+$ thymus cells } & 1 & 2 & $(-)$ & 3 & $(-)$ \\
\hline & 2 & 1 & $(-)$ & 1 & $(-)$ \\
\hline & 3 & 3 & $(-)$ & 2 & $(-)$ \\
\hline \multirow{3}{*}{ nu/nu no thymus cells } & 4 & 0 & $(-)$ & 2 & $(-)$ \\
\hline & 5 & 0 & $(-)$ & 1 & $(-)$ \\
\hline & 6 & 2 & $(-)$ & 4 & $(-)$ \\
\hline \multirow{6}{*}{$\mathrm{nu} /+$} & 7 & 3 & 3 & 2 & 1 \\
\hline & 8 & 4 & 3 & 4 & 1 \\
\hline & 9 & 5 & 3 & 3 & 1 \\
\hline & 10 & 3 & 3 & 2 & 1 \\
\hline & 11 & 4 & 3 & 1 & 0 \\
\hline & 12 & 4 & $(-)$ & 2 & 0 \\
\hline $\mathrm{BALB} / \mathrm{c}$ & 13 & 7 & 5 & 5 & 5 \\
\hline
\end{tabular}

* The titer is expressed by $\mathrm{x}$ in $10 \times 2^{\mathrm{x}}$.

Table 2 In vitro transformation of mouse spleen cells to Mycobacterium leprae antigens

\begin{tabular}{|c|c|c|c|c|c|c|c|}
\hline \multirow{3}{*}{ Mouse } & \multirow{3}{*}{$\begin{array}{l}\text { No. of } \\
\text { animal }\end{array}$} & \multirow{3}{*}{$\begin{array}{l}\text { Week of } \\
\text { sacrifice }\end{array}$} & \multicolumn{5}{|c|}{${ }^{3} \mathrm{H}$-thymidin uptake of cells with } \\
\hline & & & \multirow{2}{*}{$\begin{array}{c}\text { no antigen } \\
\text { cpm }\end{array}$} & \multicolumn{2}{|c|}{$2.5 \times 10^{6}$ bacilli } & \multicolumn{2}{|c|}{$5 \times 10^{6}$ bacilli } \\
\hline & & & & $\operatorname{cpm}$ & S.I.* & $\mathrm{cpm}$ & S.I.* \\
\hline \multirow{3}{*}{$\mathrm{nu} / \mathrm{nu}+$ thymus cells } & 1 & 5.5 & 1517 & - & - & {$[252$} & 0.83 \\
\hline & 2 & 5.5 & 3642 & - & - & 3632 & 1.00 \\
\hline & 3 & 5.5 & 1227 & - & - & 1745 & 1.42 \\
\hline \multirow{3}{*}{$\mathrm{nu} / \mathrm{nu}$ no thymus cells } & 4 & 5.5 & 3003 & - & - & 2402 & 0.80 \\
\hline & 5 & 5.5 & 3021 & - & - & 1833 & 0.61 \\
\hline & 6 & 5.5 & 1886 & - & - & 1698 & 0.90 \\
\hline \multirow{3}{*}{$\mathrm{nu} /+$} & 10 & 4 & 1239 & 1205 & 0.97 & 693 & 0.56 \\
\hline & 11 & 4 & 210 & 139 & 0.66 & 134 & 0.64 \\
\hline & 12 & 4 & 362 & 356 & 0.92 & 410 & 1.13 \\
\hline \multirow{4}{*}{ Conventional $\mathrm{BALB} / \mathrm{c}$} & 13 & 4 & 4177 & - & 一 & 4594 & 1.10 \\
\hline & 14 & 16 & 357 & - & - & 682 & 1.91 \\
\hline & 16 & 16 & 811 & - & - & 867 & 1.07 \\
\hline & 17 & 16 & 791 & - & - & 907 & 1.15 \\
\hline
\end{tabular}

* S.I. = stimulation index

sponse which was shown by the stimulation index larger than 1 . However, only one nude mouse (No. 3) caused positive response after the transfusion of thymus cells from nu/ + donors followed by the second injection of antigens, while the other nude mice receiving no thy- 
mocyte remained negative. Among three conventional BALB/c mice sacrificed at 16 th week, one mouse (No. 14) also showed positive response. Therefore, if the thymocyte-transfer and the test with spleen cells would be performed at far late stage, more intense response in the recipient mice might be observed. Such condition must be considered in future study.

It is generally known that CMI to intracellular parasite is actively induced when the microorganisms are able to multiply to some extent in the host cells ${ }^{7}$. Since the presence of viable bacilli in the material could not be confirmed, relatively large number of $M$. leprae was injected intravenously. In such condition, a large quantity of antigens liberated from dead bacilli may activate B-cell system and lead to early production of antibodies without inducing CMI. Even if competent $T$ cells are activated, but if insufficient in their number, large quantity of antigens may deplete the function of $\mathrm{T}$ cell system. Such mechanism, i.e., immunoparalysis, may operate in these mice at early immune response to $M$. leprae infection, and this may be a model of indeterminate leprosy having a tendency to lepromatous type.

On the other hand, if small number of viable $M$. leprae are infected locally, they are ingested in phagocytes, and processed antigens or direct cell-cell contact may activate $\mathrm{T}$ cell system without inducing antibody response. This may be another course of indeterminate leprosy having a tendency to tuberculoid type. If similar processes are realized in nude mouse by passive transfer of CMI, it will provide us very useful model for the studies on prophylaxis and therapy of lepromatous leprosy.

\section{Summary}

For the purpose of elucidating immune mechanism in early stage of leprosy, three strains of mice, conventional $\mathrm{BALB} / \mathrm{c}$, SPF $\mathrm{BALB} / \mathrm{c}-\mathrm{nu} /+$ and $\mathrm{BALB} / \mathrm{c}-\mathrm{nu} / \mathrm{nu}$ mice, were injected intravenously with a mixture of $10^{7} \mathrm{M}$. leprae and $10^{8}$ sheep red blood cells. All of these mice showed similar degree of antibody response to $M$. leprae, as demonstrated by indirect immunofluorescence, the antibody-titer reaching to the maximum within a week after the injection of antigens. The production of $\operatorname{IgG}$ antibodies was somewhat delayed and the titer reached to a plateau within 2 or 3 weeks. No decline of antibody-titer was observed till at least 5 weeks after the injection of antigens. The transfer of thymocytes from immunized $\mathrm{nu} /+$ donors to $\mathrm{nu} / \mathrm{nu}$ recipients did not influence the antibody-titer in the recipient.

Both agglutinins and hemolysins to sheep red blood cells were less produced in nu/nu mice than in nu/t and conventional mice. After the transfer of thymocytes followed by second injection of antigens, nude mice showed low level of antibody response which was sensitive to mercapto-ethanol treatment. In vitro transformation of spleen cells to $M$. leprae antigens was not caused by any of mice, except for positive response by one nude mouse in to which thymocytes from immunized donor and second injection of antigens were given.

From these observations it may be concluded that the production of anti- $M$. leprae antibodies is thymus-independent and that this immune response can be induced at early stage of leprosy infection without induction of cell-mediated immunity. 


\title{
Acknowledgement
}

This investigation was partially supported by the grant of US-Japan Cooperative Medical Science Program and that of Ohyama Health Foundation.

\section{References}

1) H N. Claman \& D. E. Mosier: Cell-cell interaction in antibody production. Progr. Allergy, 16, 40-80, (1972).

2) M. Abe et al: Production of anti-M. leprae antibodies in man and mice under the impairment of cell-mediated immunity. Internat. J. Leprosy, 44, 234-242, (1976).

3) J. Rygaard \& C. O. Povlson (ed.): Proceeding of the first international workshop on nude mice. Gustav Fisher Verlag. Stuttgart, (1974).

4) K. Kohsaka, T. Mori \& T. Ito: Lepromatoid lesion developed in nude mouse inoculated with Mycobacterium leprae. La Lepro, 45, 177-188, (1977).

5) M. Abe, S. Izumi, T. Saito \& S. K. Mathur: Early serodiagnosis of leprosy by indirect immunofluorescence. Leprosy in India, 48, 272-276, (1976).

6) H. F. Clark \& C. C. Shepard: A dialysis technique for preparing fluorescent antibody. J. Virol. 20, 642-644, (1973).

7) A. C. Allison et al: Cell-mediated immunity and resistance to infection. WHO Technical Report Series No. 519, Geneva, (1973).

\section{らい菌の静脈注射後に惹起されるヌードマウスの 早期免疫応答}

\author{
皆川 文重・吉野 勇次・阿部 正英 \\ (国立多摩研究所)
}

(受付：1977 年8月 18 日)

\section{らいの初期免疫機構を明らかにするために，通常の} $\mathrm{BALB} / \mathrm{c}, \mathrm{SPF}$ の BALB/c-nu/+ 及び BALB/c-nu/nu の3種類のマウスに，らい菌 $10^{7}$ コとヒジ赤血球 $10^{8}$ コの混合液を静脈注射した。間接免疫螢光法でしらべた 抗らい菌抗体応答はすべてのマウスで同程度に起り，抗 体価注抗原注射後 1 週以内に最高に達した。IgG 抗体 の産生はややおくれ，抗体価は $2 \sim 3$ 週以内に水平位に 達した。抗原注射後少くとも5週以内には抗体価の減少 は認められなかった。免疫した nu/十 マウスの胸腺細 胞を nu/nu マウスに移入したが，後者の抗体価に影響 を及ぼなかった。れらの所見はらい菌に対する抗体 産生が胸腺非依存性であり，また間接螢光抗体法が感染 直後の抗体産生を見いだすのに役立つことを示してい 西。
ヒツジ赤血球に対する凝集素及び溶血素の産生は通常 の BALB/c 及び nu/+ マウスより\& nu/nu マウスで は弱く，この货疫応答が胸腺依存性であることを示し た。胸腺細胞を移入し, ついで再度抗原注射を行った が, nu/nu マウスの抗体洒は低く，抗体は 2-メルカプ トエタノール処理により失活した。

らい菌抗原に対する脾細胞のガラス器内变形反応は, 胸腺細胞を移入し，抗原再注射を行ったヌードマウスの 1 匹で陽性となったほかは，どのマウスでも陰性であっ た。これは大量のらい菌抗原の静脈注射が $\mathrm{T}$ 細胞の枯 渴を起した故かも知れない。このような, 細胞性免疫の 誘導なしに液性免疫忍答が感染初期に起ることは，らい 腫型に傾き易い未定型らいのモデルをあらわすように思 われる。 